\title{
Screening of 'King' Mandarin Hybrids as Tolerant Citrus Rootstocks to Flooding Stress
}

\author{
Mary-Rus Martínez-Cuenca *D, Amparo Primo-Capella and María Ángeles Forner-Giner * \\ Department of Citriculture and Vegetal Production, Valencian Institute for Agricultural Research-IVIA, Crta. \\ CV-315, 46113 Moncada, Spain; primo_amp@gva.es \\ * Correspondence: martinez_mru@gva.es (M.-R.M.-C.); forner_margin@gva.es (M.-Á.F.-G.); \\ Tel.: +34-963424000 (M.-R.M.-C. \& M.-Á.F.-G.); Fax: +34-963424001 (M.-R.M.-C. \& M.-Á.F.-G.)
}

Citation: Martínez-Cuenca, M.-R.;

Primo-Capella, A.; Forner-Giner, M.Á Screening of 'King' Mandarin

Hybrids as Tolerant Citrus Rootstocks to Flooding Stress. Horticulturae 2021, 7, 388. https://doi.org/10.3390/ horticulturae7100388

Academic Editor: Sergio

Ruffo Roberto

Received: 2 August 2021

Accepted: 16 September 2021

Published: 11 October 2021

Publisher's Note: MDPI stays neutral with regard to jurisdictional claims in published maps and institutional affiliations.

Copyright: (c) 2021 by the authors. Licensee MDPI, Basel, Switzerland. This article is an open access article distributed under the terms and conditions of the Creative Commons Attribution (CC BY) license (https:// creativecommons.org/licenses/by/ $4.0 /)$.
Abstract: This work compares the tolerance to long-term anoxia conditions (35 days) of five new citrus 'King' mandarin (Citrus nobilis L. Lour) $\times$ Poncirus trifoliata ((L.) Raf.) hybrids (named 0501XX) and Carrizo citrange (CC, Citrus sinensis (L.) Osb. $\times$ Poncirus trifoliata (L.) Raf.), the widely used citrus rootstock in Spain. Growth parameters, chlorophyll concentration, gas exchange and fluorescence parameters, water relations in leaves, abscisic acid (ABA) concentration, and PIP1 and PIP2 gene expressions were assessed. With a waterlogging treatment, the root system biomass of most hybrids went down, and the chlorophyll a and $\mathrm{b}$ concentrations substantially dropped. The net $\mathrm{CO}_{2}$ assimilation rates (An) and stomatal conductance $\left(g_{s}\right)$ lowered significantly due to flooding, and the transpiration rate (E) closely paralleled the changes in $g_{s}$. The leaf water and osmotic potentials significantly increased in most 0501 hybrids. As a trend, flooding stress lowered the ABA concentration in roots from most hybrids, but increased in the leaves of CC, 05019 and 050110 . Under the control treatment $(\mathrm{Ct})$ conditions, most 0501 hybrids showed higher PIP1 and PIP2 expressions than the control rootstock CC, but were impaired due to the flooding conditions in 05019 and 050110. From this study, we conclude that 0501 genotypes develop some adaptive responses in plants against flooding stress such as (1) stomata closure to prevent water loss likely mediated by ABA levels, and (2) enhanced water and osmotic potentials and the downregulation of those genes regulating aquaporin channels to maintain water relations in plants. Although these traits seemed especially relevant in hybrids 050110 and 050125, further experiments must be done to determine their behavior under field conditions, particularly their influence on commercial varieties and their suitability as flooding-tolerant hybrids for replacing CC, one of the main genotypes that is widely used as a citrus rootstock in Spain, under these conditions.

Keywords: ABA; chlorophyll concentration; Citrus hybrids; fluorescence; gas exchange parameters; osmotic potential; PIPs; water potential; waterlogging

\section{Introduction}

Soil flooding is a major abiotic stress that negatively impacts many agricultural crops and leads to significant economic losses [1]. This disorder affects large areas worldwide and is generally related to poor soil drainage combined with excessive rainfall or irrigation. The effects of soil flooding on plants are mainly related to declining aerobic root respiration, which induces a variety of physiological disturbances that alter plant growth [2], including reductions in water flux from roots, hormonal imbalances, altered carbohydrate distribution, deficient nutrient uptake, early leaf senescence, and injury to organs, which sometimes lead to plant death [3].

A widely applied system to prevent abiotic stresses in fruit tree crops involves the use of tolerant genotypes as rootstocks [4-8]. For this purpose, the flooding tolerance of citrus rootstocks has been tested in several studies [4,9-12]. However, the availability of citrus rootstocks that combine positive plant responses, such as tolerance to iron chlorosis, 
CTV (citrus tristeza virus), and Phytophthora spp., is still scarce. Therefore, searching for new rootstocks that cover all three characteristics is essential. To this end, the Valencian Institute of Agrarian Research (IVIA) in Valencia (Spain) has undertaken an ambitious breeding program of citrus rootstocks to evaluate the behavior of new citrus rootstocks against several abiotic disorders such as salinity, flooding, or iron chlorosis [13-16]. One of the combinations in this program included the hybrids of King mandarin (tolerant to bicarbonate and Phytophthora) and Poncirus trifoliata (tolerant to CTV), known as 0501 hybrids. As conventional breeding is very slow for woody trees, physiological screening methods represent an excellent tool for the quick characterization of new citrus genotypes' response to flooding conditions.

Plant growth (dry biomass, root/shoot ratio), chlorophyll concentrations, photosynthetic activity, and fluorescence are common determinations used to evaluate stress tolerance in plants $[11,15,17,18]$. Some species have acquired certain characteristics that allow adaptation to anaerobic conditions [19]. Plant strategies to grow and survive during long waterlogging periods include biochemical, anatomical, and morphological changes [3].

Although the response is variable between hybrids and cultivars, Citrus is considered a flooding-sensitive crop that responds to waterlogging by restricting stomatal conductance to prevent water loss $[9,20]$. This fact appears to be hormone-regulated and is associated with abscisic acid (ABA) accumulating mainly in leaves, which induces stomatal closure $[20,21]$. Under these conditions, net $\mathrm{CO}_{2}$ assimilation by leaves is subsequently reduced $[9,22,23]$, which leads to altered carbohydrate distribution [24]. Photosynthetic system impairment may also generate excess reactive oxygen species (ROS) and result in oxidative cell damage $[21,25,26]$. During prolonged soil flooding periods, reduced root hydraulic conductance $[12,20,27]$ impairs water uptake, which causes leaf wilting and chlorosis [25]. In addition, flooded plants present a low water flux with high evaporative demand, which seems to be due to the downregulation of root hydraulic conductance by anoxia [28,29], associated with stomatal closure [12,30-33]. It is generally accepted that water transport across biological membranes is facilitated by aquaporins. These proteins belong to the major intrinsic proteins (MIPs) family [34] and form water channels that facilitate the passive flow of water through cell membranes and maintain water content in cells and tissues [35]. There is some evidence that, among aquaporins, the subfamily of plasma membrane intrinsic proteins (PIPs) appears to play a critical role in controlling water transport through root tissues by regulating the transcellular pathway [36]. Adapting root hydraulic conductance to altered environmental conditions may result from changes in the abundance or activity of aquaporins [37]. To support this, some pieces of evidence indicate a reduction in the expression of genes PIP1 and PIP2 by anoxia. Furthermore, the root signals and sensory mechanisms that trigger citrus responses to flooding have been recently described $[20,21]$.

The main objective of this work was to evaluate the response of five new citrus rootstocks under flooding conditions according to several determinations related to growth, photosynthetic capacity, water relations, ABA concentration, and gene expression of the key aquaporins involved in the water transport process in the root system. For this purpose, assays were carried out in five different combinations of 'King' mandarin (Citrus nobilis L. (Lour) $\times$ Poncirus trifoliata (L.) Raf.) mother trees (named 0501 hybrids), which were compared to the seedlings of Carrizo citrange (CC), one of the main genotypes that is widely used as citrus rootstocks in Spain as a moderate flooding-tolerant hybrid [20].

\section{Materials and Methods}

\subsection{Plant Material and Growth Conditions}

The seeds from five citrus hybrids, a combination of 'King' mandarin (Citrus nobilis L. (Lour) $\times$ Poncirus trifoliata (L.) Raf.) mother trees (named 0501 hybrids: 05019, 050110, 050119, 050120, and 050125) and CC (hybrid of Citrus sinensis (L.) Osb. $\times$ Poncirus trifoliata (L.) Raf.), were germinated in a glasshouse in a sterile substrate that comprised peat, coconut fiber, sand, and perlite (50:25:20:5) supplemented with $1.38 \mathrm{~g} \cdot \mathrm{kg}^{-1}$ cal- 
cium superphosphate. They were irrigated twice weekly with the following nutrient solution [24]: $3 \mathrm{mM} \mathrm{Ca}\left(\mathrm{NO}_{3}\right)_{2}, 3 \mathrm{mM} \mathrm{KNO}_{3}, 2 \mathrm{mM} \mathrm{MgSO}_{4}, 2.3 \mathrm{mM} \mathrm{H}_{3} \mathrm{PO}_{4}, 17.9 \mu \mathrm{M}$ Fe-EDDHA, $46.25 \mu \mathrm{M} \mathrm{H}_{3} \mathrm{BO}_{3}, 54.4 \mu \mathrm{M} \mathrm{MnSO}_{4} \cdot \mathrm{H}_{2} \mathrm{O}, 7.65 \mu \mathrm{M} \mathrm{ZnSO}_{4} \cdot 7 \mathrm{H}_{2} \mathrm{O}, 0.55 \mu \mathrm{M} \mathrm{MoO}_{3}$, and $0.5 \mu \mathrm{M} \mathrm{CuSO}_{4} \cdot 5 \mathrm{H}_{2} \mathrm{O}$. The nutrient solution $\mathrm{pH}$ was adjusted to 6.5 with $1 \mathrm{M} \mathrm{KOH}$ or $1 \mathrm{M} \mathrm{H}_{2} \mathrm{SO}_{4}$. Seedlings were grown under glasshouse conditions with supplementary light $\left(250 \mu \mathrm{mol} \cdot \mathrm{m}^{-2} \cdot \mathrm{s}^{-1}, 400-700 \mathrm{~nm}\right)$ to extend the photoperiod to $16 \mathrm{~h}$. Temperatures ranged from $16-18{ }^{\circ} \mathrm{C}$ at nighttime and $26-28^{\circ} \mathrm{C}$ in the daytime. Relative humidity (RH) was maintained at approximately $80 \%$.

After 8 months, seedlings were selected according to uniformity of size and were transplanted individually to opaque plastic $500 \mathrm{~mL}$ pots filled with coarse sand. Seedlings were irrigated twice weekly until the beginning of the experiment with $250 \mathrm{~mL}$ of the previous nutrient solution ( $\mathrm{pH}$ 6.5). Seedlings were maintained under the same previously described glasshouse conditions. Excess solution was drained from pots to prevent salt from accumulating in sand.

After 1 month, seedlings ( $n=20$ per genotype and treatment) were randomly divided into two uniform groups. One group (Control, $\mathrm{Ct}$ ) was watered normally and well drained (as indicated previously). The other group (Flooding) was maintained under imposed continuous waterlogging conditions. The Flooding group was placed inside separate plastic water tanks $(49 \times 39 \times 14 \mathrm{~cm})$ and underwent waterlogging stress treatment by immersing pots in nutrient solution. Whenever necessary, the nutritive solution was supplemented to maintain the water level $4 \mathrm{~cm}$ above the sand surface. An opaque plastic sheet was used to cover container surfaces to avoid algal proliferation. Seedlings were randomized over the experimental area. A row of plants, which was not included in the experiment, was placed around the perimeter as a buffer row. Plants were maintained under the same previously described glasshouse conditions for 35 days. Then seedlings were carefully removed from pots, and roots were washed with tap water to remove sand. Finally, whole seedlings were rinsed with deionized water before being processed for further measurements.

\subsection{Growth Parameters}

Six seedlings per treatment were separated into leaves, stems, and roots, followed by rinsing with tap water and distilled water containing a nonionic detergent $(50 \mathrm{mM}$ $\mathrm{HCl}$ ), and rinsing three times in distilled water. The dry weight (DW) of each fraction was determined after drying at $70{ }^{\circ} \mathrm{C}$ to constant weight.

\subsection{Chlorophyll Concentration}

The leaf chlorophyll concentration (Chl) per DW was spectrophotometrically measured (Lambda 25, PerkinElmer, Shelton, CT, USA) according to Moran and Porath [38]. Leaf samples were lyophilized and ground to a fine powder by a laboratory ball mill (Retsch MM301, Haan, Germany). Dried tissues (0.05 g) were incubated in $6 \mathrm{~mL}$ of $\mathrm{N}, \mathrm{N}$ dimethylformamide at $4{ }^{\circ} \mathrm{C}$ for $24 \mathrm{~h}$ and centrifuged for $15 \mathrm{~min}$ at $6000 \times \mathrm{g}$ and $4{ }^{\circ} \mathrm{C}$. The supernatant was left for $1 \mathrm{~h}$ in the presence of $\mathrm{Na}_{2} \mathrm{SO}_{4}$, and its absorbance was measured at 664 and $647 \mathrm{~nm}$ (Lambda 25, PerkinElmer, Shelton, CT, USA). Measurements were taken on the two youngest fully expanded leaves of six plants per treatment. The average value of the two leaves was considered representative of each individual plant.

\subsection{Gas Exchange Parameters}

The photosynthetic activity (net $\mathrm{CO}_{2}$ assimilation rate, $\mathrm{An}$ ), transpiration rate (E), stomatal conductance $\left(\mathrm{g}_{\mathrm{s}}\right)$, and internal $\mathrm{CO}_{2}$ concentration $(\mathrm{Ci})$ of the single attached leaves were measured outdoors on a sunny day between 10:00 and 11:30 a.m., which allowed measurements to be taken under relatively stable conditions. In addition, parameters $\mathrm{An} / \mathrm{Ci}$ and $\mathrm{An} / \mathrm{E}$ were calculated as instantaneous carboxylation and water use efficiency, respectively. Photosynthetically active radiation (PAR) on the leaf surface was adjusted to a photon flux density of $1000 \mu \mathrm{mol} \cdot \mathrm{m}^{-2} \cdot \mathrm{s}^{-1}$. Closed gas exchange (CIRAS-2, PP-systems, Hitchin, UK) was used for measurements. Leaf laminae were fully enclosed inside a 
PLC 6 (U) universal leaf autocuvette in a closed0circuit model and kept at $25 \pm 0.5{ }^{\circ} \mathrm{C}$ with a leaf-to-air vapor deficit of about $1.7 \mathrm{~Pa}$. The air flow rate through the cuvette was 500-1500 $\mathrm{mL} \cdot \mathrm{min}^{-1}$. Ten consecutive measurements were taken at $3 \mathrm{~s}$ intervals. Measurements were taken on the two youngest and well developed (fully expanded) leaves of six replicates per treatment. The average value of the two leaves was considered representative of each individual plant.

\subsection{Fluorescence}

The chlorophyll fluorescence parameters (Fo: minimal fluorescence, Fm: maximal fluorescence, and $\mathrm{Fv}=\mathrm{Fm}-\mathrm{Fo}$ : variable fluorescence) were recorded with a portable chlorophyll fluorometer (PAM-2100, Heinz Walz GmbH, Germany). After 30 min of dark adaptation, leaves were illuminated with a saturating pulse of $2100 \mu \mathrm{mol}$ quanta. $\mathrm{m}^{-2} \cdot \mathrm{s}^{-1}$ for $5 \mathrm{~s}$, and Fo and Fm were measured. Measurements were taken on the two youngest and well-developed (fully expanded) leaves of six replicates per treatment. The average value of the two leaves was considered representative of each individual plant.

\subsection{Leaf Water Relations}

Leaf water potential $(\Psi \omega)$ was measured at daybreak (06:30-07:30 a.m.) with a Scholander-type pressure chamber (Soilmoisture Equipment Corp., Santa Barbara, CA, USA). After measurements, leaves were tightly wrapped in aluminum foil, frozen by immersing in liquid nitrogen, and stored in a freezer at $-80^{\circ} \mathrm{C}$. After thawing, the leaf osmotic potential $\left(\Psi_{\pi}\right)$ was measured in the extruded cell sap collected at $25 \pm 1{ }^{\circ} \mathrm{C}$ using a syringe and placed inside an osmometer (Digital Osmometer, Wescor, Logan, UT, USA).

Similar sized leaves from each plant were weighed to determine leaf fresh weight (FW). Then, leaf petioles were blotted dry with paper towels and placed in a beaker of water overnight in the dark to fully hydrate leaves. These leaves were reweighed to obtain their turgid weight (TW) and dried at $80^{\circ} \mathrm{C}$ for $24 \mathrm{~h}$ to obtain their DW. The relative water content $($ RWC $)$ of leaves was calculated as RWC $=(F W-D W)-(T W-D W)^{-1} \times 100$.

In both experiments, evaluations were made using two uniform fully expanded mature leaves from the mid-stem zone for all six replicates per treatment. The average value of the measurements taken on the two leaves was taken as being representative of each individual plant.

\subsection{ABA Analysis}

Samples of fibrous roots and leaves were collected, washed, fresh weighed, frozen with liquid nitrogen, lyophilized, dry weighed, and ground. The ABA quantification procedure was that described in [20]. Samples were extracted with $80 \%$ ethanol, and further purification was obtained with C18 Sep-Pak cartridges and reverse-phase highperformance liquid chromatography (HPLC). A fraction of the HPLC containing ABA was methylated and analyzed using a gas chromatograph (Varian Star 3400 CX, LabX, Midland, ON, Canada) coupled to a mass spectrometer (Varian Saturn, LabX, Midland, ON, Canada). Samples (1-2 $\mu \mathrm{L}$ ) were injected in splitless mode, the He inlet pressure was $85 \mathrm{kPa}$, and the injector, interface, and MS source temperatures were 250,250 , and $200{ }^{\circ} \mathrm{C}$, respectively. ABA was quantified using internal standards [39]. The base peaks of the standard and deuterated $\left[{ }^{2} \mathrm{H}_{6}\right]-\mathrm{ABA}$ (190 and $194 \mathrm{~m} / \mathrm{z}$, respectively) were monitored for $\mathrm{ABA}$ identification and quantification.

\subsection{RNA Extraction and Real-Time RT-PCR Analysis}

The total plant RNA from root tissues was extracted using the RNeasy Plant Mini Kit (Qiagen, Hilden, Germany). Fresh samples were collected, frozen in liquid nitrogen, and ground in $\mathrm{N}_{2}$ in a mortar. RNA was extracted from $0.1 \mathrm{~g}$ of fresh material. To remove genomic DNA, the RNA samples were treated with RNase-free DNase (Qiagen) following the manufacturer's instructions. RNA quality and concentration were assessed with an ND1000 full-spectrum UV-Vis spectrophotometer (Nanodrop Technologies, Thermo Fisher 
Scientific, DE, USA). Quantitative real-time polymerase chain reactions (RT-PCR) were run in a LightCycler 2.0 Instrument (Roche, Diagnostics GmbH, Mannheim, Germany) equipped with version 4.0 of the Light Cycler software. Reactions contained 2.5 units of MultiScribe Reverse Transcriptase (Applied Biosystems, Roche Molecular Systems, NJ, USA), 1 unit of RNase Inhibitor (Applied Biosystems), $2 \mu \mathrm{L}$ of LC Fast Start DNA Master PLUS SYBR Green I (Roche), $25 \mathrm{ng}$ of total RNA, and $250 \mathrm{nM}$ of the specific forward and reverse primers in a total volume of $10 \mu \mathrm{L}$. The PCR program was run at $48{ }^{\circ} \mathrm{C}$ for $30 \mathrm{~min}$ and $95{ }^{\circ} \mathrm{C}$ for $10 \mathrm{~min}$, followed by 45 cycles at $95^{\circ} \mathrm{C}$ for $2 \mathrm{~s}, 58^{\circ} \mathrm{C}$ for $8 \mathrm{~s}$, and $72{ }^{\circ} \mathrm{C}$ for $8 \mathrm{~s}$. The fluorescent intensity data were acquired in the $72{ }^{\circ} \mathrm{C}$ extension step and were transformed into relative mRNA values using a 10-fold dilution series of an RNA sample as a standard curve. The relative mRNA levels were normalized to the total RNA amounts as previously described in [40]. All the specific primers, detailed in Table 1, were tested before the PCR reaction, and efficiency (E) near to 2 was obtained [41]. Real-time PCR efficiencies were calculated from the given slopes in LightCycler software. The corresponding $\mathrm{E}$ of one cycle in the exponential phase was calculated according to the following equation: $\mathrm{E}=10^{(-1 / \text { slope })}$ [41]. Transcripts CiclevActin and CiclevUBC4 from Citrus clementina (Ciclev; http:/ / www.phytozome.net/search.php, accessed date 6 October 2018) were used as the reference genes for mandarin [42,43]. A single-factor ANOVA and linear regression analyses were performed to examine the variation in our reference genes [44]. The specificity of the amplification reactions was assessed by post-amplification dissociation curves and by sequencing the reaction product. The relative expression was measured by the relative standard curve procedure with five points of dilutions [41]. The results were the average of three independent biological replicates with three technical replicates per biological sample.

Table 1. List of the primers used for quantitative real-time PCR.

\begin{tabular}{|c|c|c|c|}
\hline Annotation & Code $^{a}$ & $\begin{array}{c}\text { Forward/Reverse } \\
\text { Primer }\left(5^{\prime}-3^{\prime}\right)\end{array}$ & Reference \\
\hline PIP1 & Ciclev10012384 & $\begin{array}{l}\text { AGGATTACACGGAGCCACCT } \\
\text { TGCTTTTGGATTTGGACACG }\end{array}$ & [20] \\
\hline PIP2 & Ciclev10029003 & $\begin{array}{l}\text { TGTGTTCATGGTTCACTTGG } \\
\text { TGAATGGTCCAACCCAGAAG }\end{array}$ & [20] \\
\hline Actin & Ciclev10025866 & $\begin{array}{l}\text { CAGTGTTTGGATTGGAGGATCA } \\
\text { TCGCCCTTTGAGATCCACAT }\end{array}$ & [42] \\
\hline$U B C 4$ & Ciclev10009771 & $\begin{array}{l}\text { TGGACGCTTCAGTCTGTTTG } \\
\text { TCGTCAATCACCCCTTCTTT }\end{array}$ & [43] \\
\hline
\end{tabular}

${ }^{a}$ Code refers to the transcript name from Citrus clementina (Ciclev) in the database available in the International Citrus Genome Consortium (http:/ / www.phytozome.net/search.php, accessed date 6 October 2018).

\subsection{Statistical Analyses}

Data distributions were checked for normality and subjected to two statistical analyses of variance (ANOVA) with Statgraphics Plus, version 5.1 (Statistical Graphics, Englewood Cliffs, NJ, USA). One-way ANOVA was carried out to test for significant differences between treatments in each hybrid. A multifactorial analysis was also done, which consisted of two factors: (i) treatment ( $\mathrm{T}$, control vs. flooding stress); (ii) the hybrid or genotype $(G)$. The mean values were compared by the least significant differences (LSD) method at the $95 \%$ confidence level. One correlation analysis, in which the individual samples of each non-stressed or flooded hybrid $(n=12)$ were subjected to linear regression and the correlation coefficients $(r)$, was completed with some physiological parameters.

\section{Results}

\subsection{Plant Growth}

The 0501 hybrids showed differences in the DW biomass when grown under normal irrigation (Figure 1). One rootstock (05019) presented the highest twig and root system biomass (130.9\% and 36.2\% higher than CC and Ct, respectively; Figure $1 \mathrm{~b}, \mathrm{c})$. Two other 
rootstocks (050110 and 050120 ) also induced a larger root system (86.4\% and 56.3\% higher than the CC Ct seedlings), while the dry matter in leaves was lower than the CC in all the studied hybrids (Figure 1a).
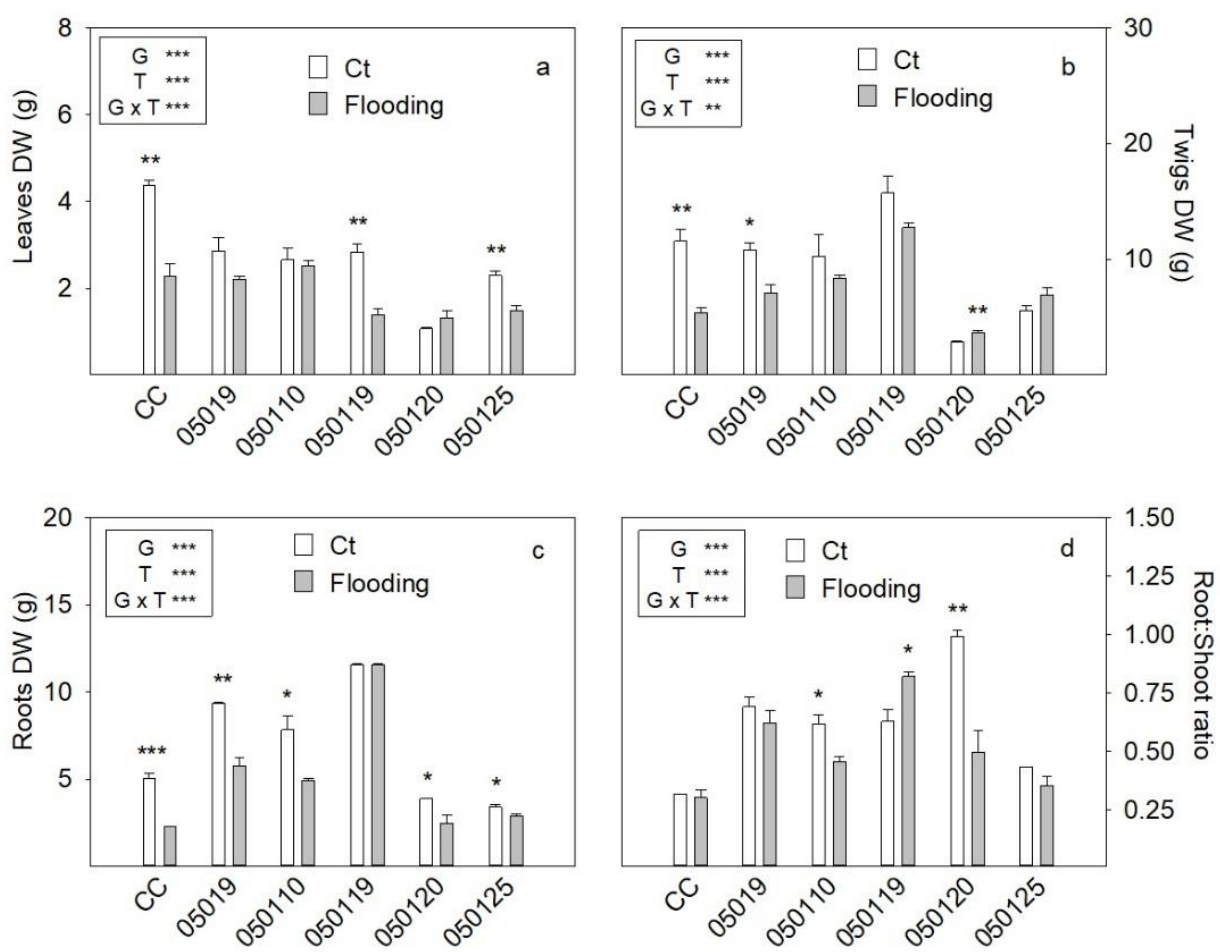

Figure 1. Dry weight (DW) in (a) leaves, (b) twigs, and (c) roots, and (d) the root-shoot ratio of five citrus hybrids grown for 35 days in the non-stressed $(\mathrm{Ct})$ or flooding treatment. Values are the means of six independent seedlings $(n=6)$. In each hybrid, comparisons among treatments were made by Fisher's least significance difference (LSD) test. ${ }^{*} p<0.05,{ }^{* *} p<0.01,{ }^{* * *} p<0.001$. CC: Carrizo citrange; G: genotype, T: treatment.

Flooding reduced the plant biomass in all the CC plant organs (between $47.6 \%$ and $55.01 \%$ ), but only affected some organs in hybrids. This reduction was more pronounced in the root system because it affected four of the five hybrids (Figure 1c). The most marked reductions in this organ were recorded for 05019 and 050110 (38.4\% and 36.9\%, respectively). In the whole aerial part, the biomass in twigs was significantly reduced by flooding in the 05019 seedlings (34.3\%) but increased in the $050120(27.46 \%)$ seedlings (Figure $1 \mathrm{~b})$. Flooding also decreased the leaf biomass in hybrids 050119 and 050125 (51.4\% and 35.4\%, respectively, Figure 1a). The root/shoot ratio (Figure 1d) rose by $30.3 \%$ in the 050119 hybrid and lowered in genotypes 050110 and 050120 by $25.9 \%$ and $50.0 \%$, respectively.

\subsection{Chlorophyll Concentration}

Citrus hybrids presented differences in all the measurements related to Chl (Figure 2) in the leaves of the seedlings grown under the $\mathrm{Ct}$ conditions. The CC Ct leaves exhibited medium values for the $C h l a$ and $C h l b$ concentrations $\left(1237.8 \pm 59.7\right.$ and $669.5 \pm 78.7 \mu \mathrm{g}^{\prime} \mathrm{g}^{-1}$ DW, respectively), while 050119 obtained the highest values in the experiment, where Chl $a$ was $30.9 \%$ and $69.1 \%$ higher in Chl $a$ and Chl b, respectively, than for the CC Ct seedlings. The 050110 plants presented the lowest Chl values (value of $18.7 \%$ ), but higher ones for Chl b $(40.8 \%)$ than the CC Ct plants. 

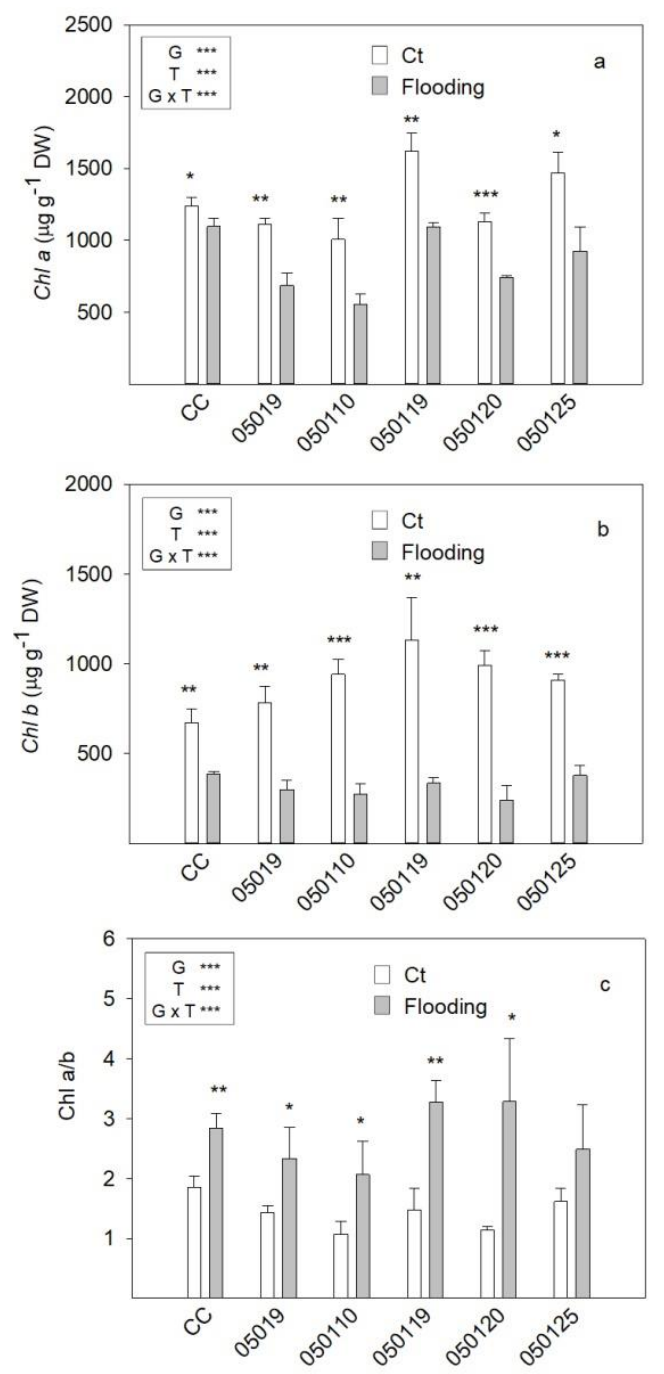

Figure 2. (a) Chlorophyll a (Chl a) concentration, (b) chlorophyll b (Chl b) concentration, and (c) the $\mathrm{Chl} a / b$ ratio in young and well developed (fully expanded) leaves of five citrus hybrids grown for 35 days in the non-stressed $(\mathrm{Ct})$ or flooding treatment. Value are the means of six independent seedlings $(n=6)$. In each hybrid, comparisons among treatments were made using Fisher's least significance difference (LSD) test. ${ }^{*} p<0.05,{ }^{* *} p<0.01,{ }^{* * *} p<0.001$. CC: Carrizo citrange; G: genotype, T: treatment.

After exposing plants to flooding, all the hybrids developed yellowness symptoms on apical leaves. The CC flooded leaves showed average reductions of $32.7 \%$ and $64.6 \%$ in the Chl $a$ and $C h l b$ concentrations compared to the Ct ones. The reduction in Chl a was even more marked in all the 0501 hybrids than in CC (between 32.6\% and $44.9 \%$ ), and the most marked reduction was recorded for 050110 . In contrast, $\mathrm{Chl} b$ concentration lowered more drastically because of flooding treatment. Three hybrids (050110, 050119, and 050120) were highlighted for their sharp drop in $\mathrm{Chl} b$ related to their corresponding CC seedlings (between $70.3 \%$ and $75.5 \%$ ).

Similarly to $\mathrm{CC}$ behavior, the $\mathrm{Chl} a / b$ ratio (Figure $2 \mathrm{c}$ ) rose due to flooding stress in all the rootstocks, including CC. The greatest increments were for 050120, 050119, and 050110 $(186.9 \%, 121.1 \%$, and $92.3 \%$, respectively).

\subsection{Gas Exchange Parameters}

The gas exchange values in the young leaves of the $\mathrm{Ct}$ and flooded Citrus seedlings are shown in Figure 3. Although differences were observed in the net $\mathrm{CO}_{2}$ assimilation rates (An, Figure 3a) in the Ct plant leaves (from 4.6 to $11.7 \mu \mathrm{mol} \mathrm{CO}_{2} \cdot \mathrm{m}^{-2} \cdot \mathrm{s}^{-1}$ ), these values 
fell within the optimal range for citrus plants. The highest An value was for the $050125 \mathrm{Ct}$ leaves (nearly twofold higher than CC Ct). However, this parameter was significantly lowered due to flooding in all the rootstocks, including CC. The major reductions were for 050109,05010 , and 050125 (between $81.6 \%$ and $88.6 \%$ ) while the lowest was found in $050120(58.3 \%)$.
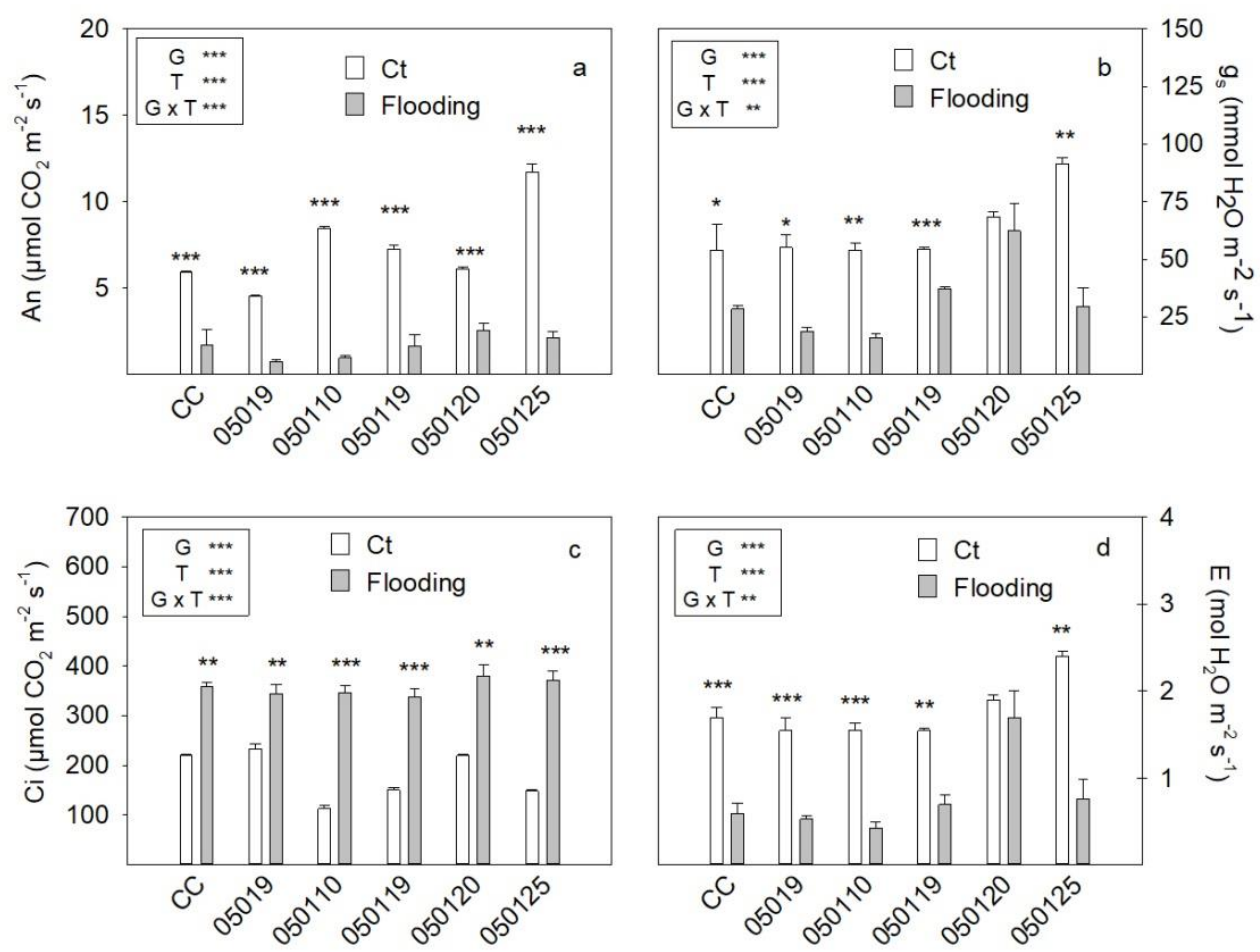

Figure 3. (a) Net photosynthesis (An), (b) stomatal conductance $\left(\mathrm{g}_{\mathrm{s}}\right)$, (c) internal $\mathrm{CO}_{2}$ concentration (Ci), and (d) evapotranspiration (E) measured in young and well-developed (fully expanded) leaves from five citrus hybrids grown for 35 days in the non-stressed $(\mathrm{Ct})$ or flooding treatment. Values are the means of six independent seedlings $(n=6)$. In each hybrid, comparisons among treatments were made by Fisher's least significance difference (LSD) test. ${ }^{*} p<0.05,{ }^{* *} p<0.01$, *** $p<0.001$. CC: Carrizo citrange; G: genotype, T: treatment.

Under the $\mathrm{Ct}$ conditions, two 0501 hybrids obtained greater $\mathrm{g}_{\mathrm{s}}$ values (Figure $3 \mathrm{~b}$ ) than the $\mathrm{CC}$ control rootstock $\left(54.5 \mathrm{mmol} \mathrm{H}_{2} \mathrm{O} \cdot \mathrm{m}^{-2} \cdot \mathrm{s}^{-1}\right)$. The higher $\mathrm{g}_{\mathrm{s}}$ value was observed in $050125 \mathrm{Ct}$ (1.7-fold higher than CC Ct), and it was 1.3-fold higher in $050120 \mathrm{Ct}$. Flooding decreased $\mathrm{g}_{\mathrm{s}}$ in most hybrids (Figure $3 \mathrm{~b}$ ) and ranged from $31.5 \%$ to $71.0 \%$, as recorded for stressed leaves 050119 and 050110 , respectively.

In the $\mathrm{Ct}$ seedlings, the internal $\mathrm{CO}_{2}$ concentration $(\mathrm{Ci}$, Figure $3 \mathrm{c}$ ) was low in the 050110, 050119, and 050125 leaves $\left(137.2 \pm 20.9 \mu \mathrm{mol} \mathrm{CO} \cdot \mathrm{m}^{-2} \cdot \mathrm{s}^{-1}, 37 \%\right.$ lower than CC $\mathrm{Ct})$. This parameter increased in the flooded plants. Thus the 050110 flooded genotype underwent the greatest rise $(206.2 \%)$, but increased by $125.6 \%$ and $150.1 \%$ in hybrids 050119 and 050125 , respectively. A slighter rise was observed in $05019(48.1 \%)$, which was somewhat lower than the CC seedlings (62.2\%).

Transpiration rates (E, Figure 3d) closely paralleled the changes in $\mathrm{g}_{\mathrm{s}}$. Leaves of 050110 were highlighted for their high $\mathrm{E}$ value under the $\mathrm{Ct}$ conditions $35.2 \%$ higher than the mean value of $1.8 \pm 0.34 \mathrm{mmol} \cdot \mathrm{m}^{-2} \cdot \mathrm{s}^{-1}$ ). Flooding decreased $\mathrm{E}$ in most hybrids and ranged from $54.8 \%$ to $72.1 \%$ in 050119 and 050110 , respectively. Only 050120 did not show this effect in the stressed leaves.

The two-way ANOVA revealed very significant differences for factors "genotype" and "treatment", as well as their interaction, for the instantaneous carboxylation efficiency parameter, estimated as the $\mathrm{An} / \mathrm{Ci}$ ratio (Figure 4a). Under the $\mathrm{Ct}$ conditions, three hybrids (050110, 050119, and 050125) presented a higher An/Ci ratio than CC Ct (181.6\%, 81.9\%, 
and $195.9 \%$ higher, respectively). The An/Ci ratio was significantly lower for the flooding treatment in CC and all the 0501 hybrids (ranging from $74.5 \%$ to $95.6 \%$ ) compared to their control (Ct; Figure 4a).
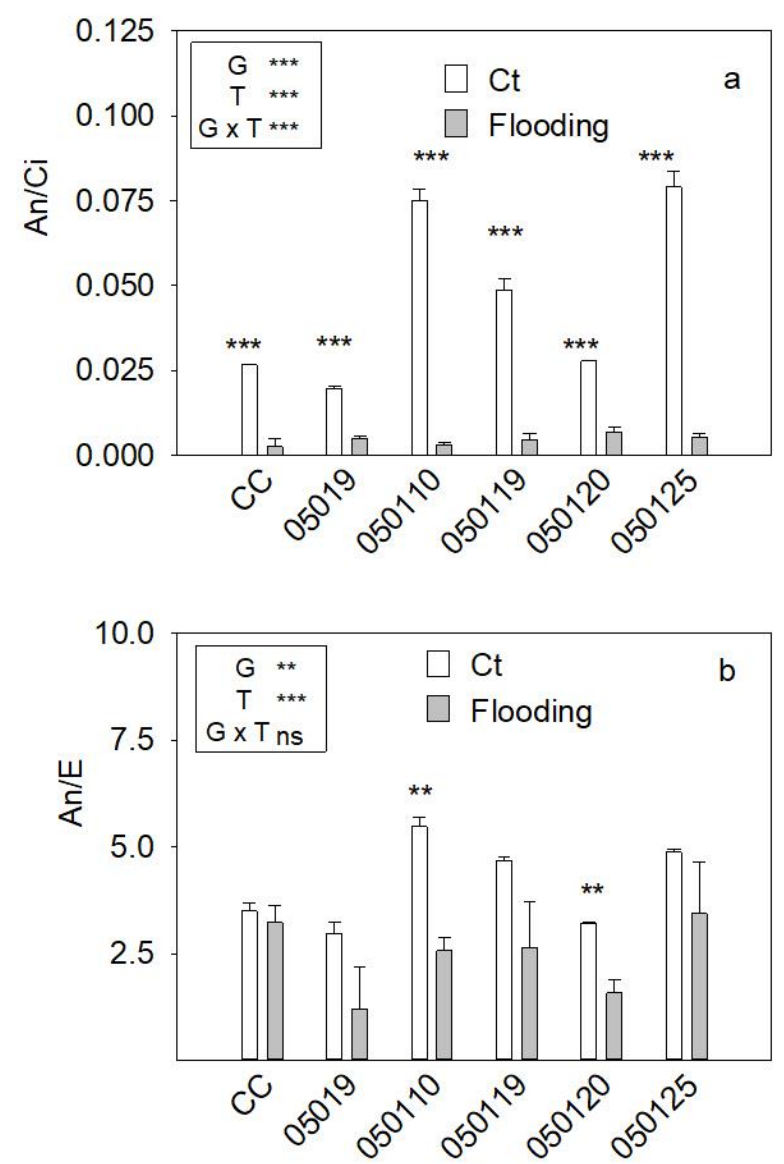

Figure 4. (a) Instantaneous carboxylation efficiency (An/Ci) and (b) instantaneous water use efficiency (An/E) in young and well-developed (fully expanded) leaves from five citrus hybrids grown for 35 days in the non-stressed $(\mathrm{Ct})$ or flooding treatment. Values are the means of six independent seedlings $(n=6)$. In each hybrid, comparisons among treatments were made by Fisher's least significance difference (LSD) test. ${ }^{* *} p<0.01,{ }^{* * *} p<0.001$, ns: not significant. CC: Carrizo citrange; G: genotype, T: treatment.

In terms of instantaneous water use efficiency, under the $\mathrm{Ct}$ conditions, three hybrids (050110, 050119, and 050125) obtained a higher An/E ratio than CC Ct $(56.5 \%, 36.6 \%$, and $39.2 \%$ higher, respectively, Figure $4 \mathrm{~b}$ ). Only two hybrids (050110 and 050120) presented a significantly lower An/Ci ratio for the flooding treatment (ranging from $74.5 \%$ to $95.6 \%$ ) compared to their $\mathrm{Ct}$ (Figure $4 \mathrm{~b}$ ).

\subsection{Fluorescence}

Under the $\mathrm{Ct}$ treatment conditions, 050110 and 050125 presented the highest Fo values (around 0.10), which rose to 0.06 in the CC and 050119 Ct leaves (Figure 5a). Flooding significantly increased the Fo value in 050119 (52.3\%). The Fm values of most of the Ct seedlings were between 0.35 and 0.47 (Figure 5b), and they rose to 0.62 in $050125 \mathrm{Ct}(49.7 \%$ higher than the mean value in the other hybrids). Three hybrids $(05019,050110$, and 050125$)$ obtained lower Fm values for the stressed seedlings compared to the $\mathrm{Ct}$ (decreases of $40.0 \%$, $46.1 \%$, and $30.8 \%$, respectively). The $\mathrm{Fv} / \mathrm{Fm}$ ratio was around 0.82 in most $\mathrm{Ct}$ leaves and flooding significantly decreased this parameter in all the hybrids (between $5.8 \%$ and $28.1 \%$ ), but not in 050125 (Figure 5c). The greatest decrement was observed in the 050110 stressed seedlings (28.1\%). The highest Fv / Fo ratio was recorded for the 050119, 050120 and 050125 
Ct leaves (mean $5.3 \pm 0.33,18.4 \%$ higher than the Ct rootstock CC Ct; Figure $5 \mathrm{~d}$ ). Flooding decreased this parameter in all the studied rootstocks (between $25.4 \%$ and $54.9 \%$ ).
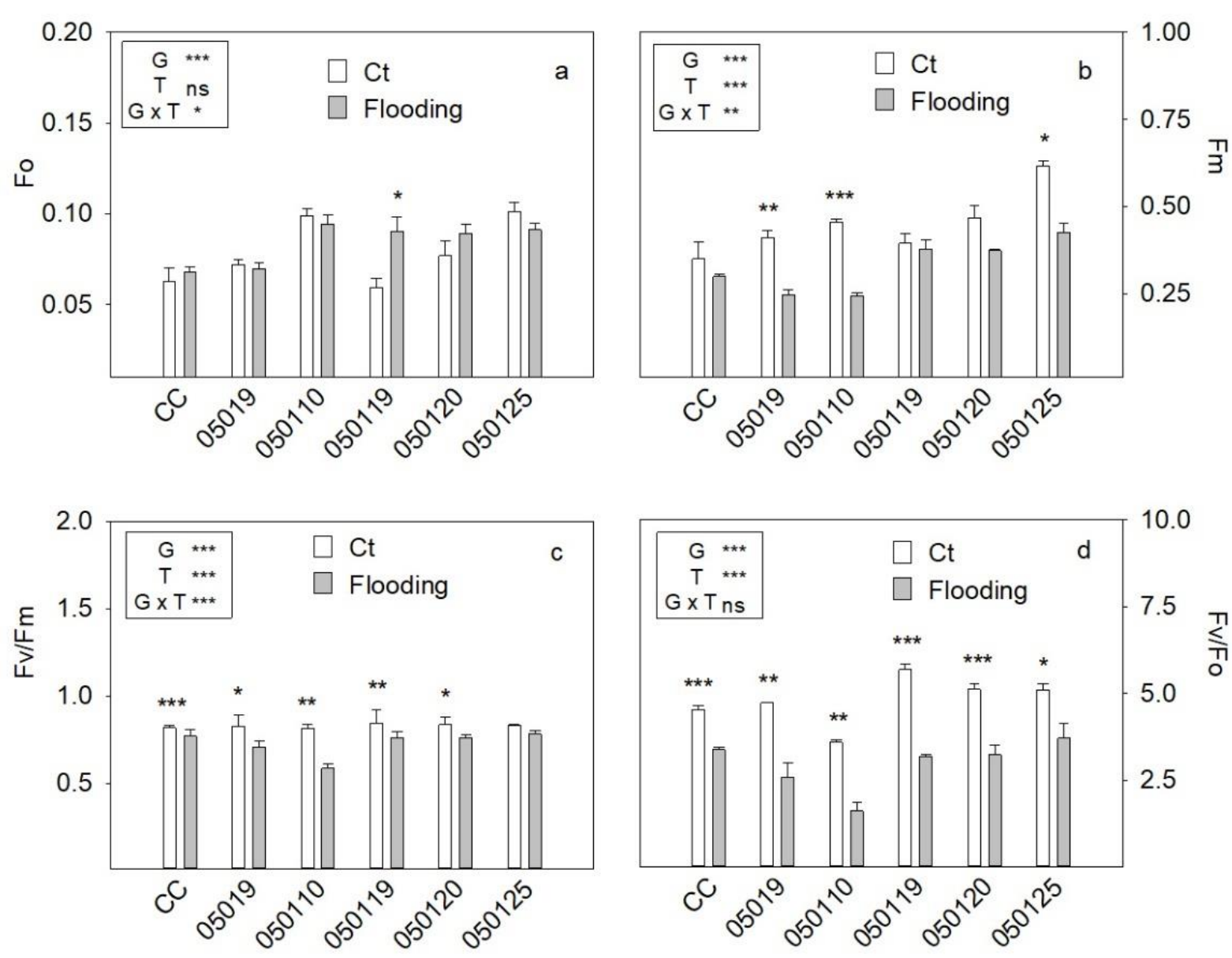

Figure 5. Fluorescence parameters (a) Fo, (b) Fm, (c) Fv/Fm, and (d) Fv/Fo) in young and well-developed (fully expanded) leaves of five citrus hybrids grown for 35 days in the non-stressed $(\mathrm{Ct})$ or flooding treatment. Values are the means of six independent seedlings $(n=6)$. In each hybrid, comparisons among treatments were made by Fisher's least significance difference (LSD) test. ${ }^{*} p<0.05,{ }^{* *} p<0.01,{ }^{* * *} p<0.001$, ns: not significant. CC: Carrizo citrange; G: genotype, T: treatment.

\subsection{Water Relation Parameters}

The leaf water potential ( $\Psi \mathrm{w}$, Figure 6a) differed between hybrids under the $\mathrm{Ct}$ conditions. The highest $\Psi w$ values were observed in 050110, 050120, and 050125 (33\% increase in relation to $\mathrm{CC} \mathrm{Ct}$ ). Flooding significantly increased this parameter in all the studied hybrids, ranging from 138.9 to 169.2 in most hybrids, including CC, 05019, 050110, and 050119 . The leaf osmotic potential values $\left(\Psi_{\pi}\right.$, Figure $\left.6 \mathrm{~b}\right)$ remained at similar levels (from -0.96 to -1.17 ) in most $C t$ seedlings. Only 050125 had a lower $\Psi_{\pi}$ value than the rest (25\% lower vs. CC Ct). Waterlogging significantly increased $\Psi_{\pi}$ (from $73.3 \%$ to $136.2 \%$ ) in CC and hybrids 050110 and 050125 . The leaf relative water content (RWC, Figure 6c) was affected only in the 050120 hybrid, which showed a $7.1 \%$ increase when plants were exposed to flooding stress. 

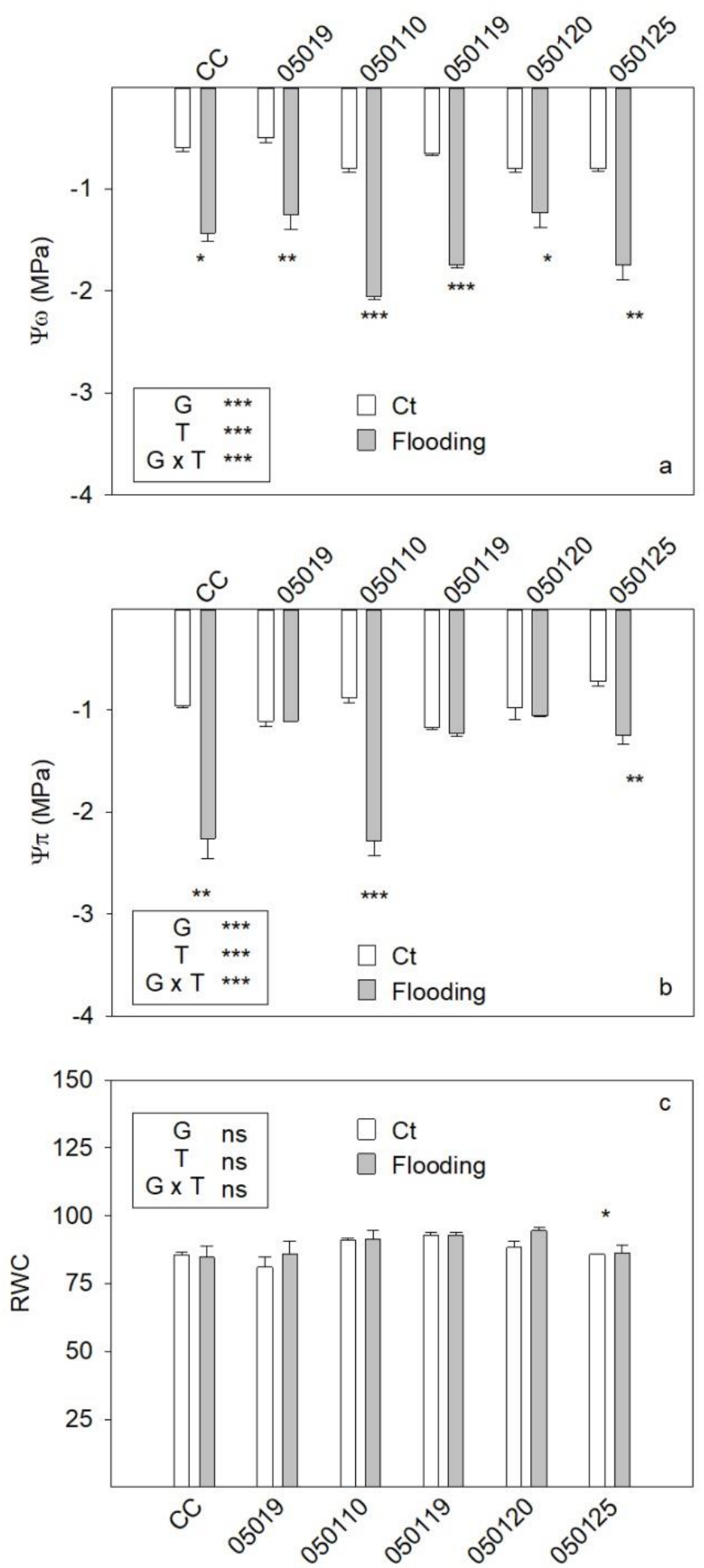

Figure 6. (a) Water potential ( $\Psi \omega)$, (b) osmotic potential $\left(\Psi_{\pi}\right)$, and (c) RWC (relative water content) in the leaves of five citrus hybrids grown for 35 days in the non -tressed $(\mathrm{Ct})$ or flooding treatment. Values are the means of six independent seedlings $(n=6)$. In each hybrid, comparisons among treatments were made by Fisher's least significance difference (LSD) test. ${ }^{*} p<0.05,{ }^{* *} p<0.01$, *** $p<0.001$, ns: not significant. CC: Carrizo citrange; G: genotype, T: treatment.

\subsection{ABA Concentration}

The leaf ABA concentration (Figure 7a) was more variable than it was in roots. Under the $\mathrm{Ct}$ conditions, all the 0501 hybrids showed a higher ABA concentration than $\mathrm{CC}$ 
(87.9 $\mathrm{ng} \cdot \mathrm{g}^{-1} \mathrm{DW}$ ). This parameter was twice as high in the 05019 and 050120 hybrids than in the $\mathrm{Ct}$, and it was 2.8-fold in 050125 (the highest value obtained in the experiment). Flooding significantly increased the leaf ABA concentration in CC, 05019, and 050110 (between $38.8 \%$ and $44.1 \%$ ).
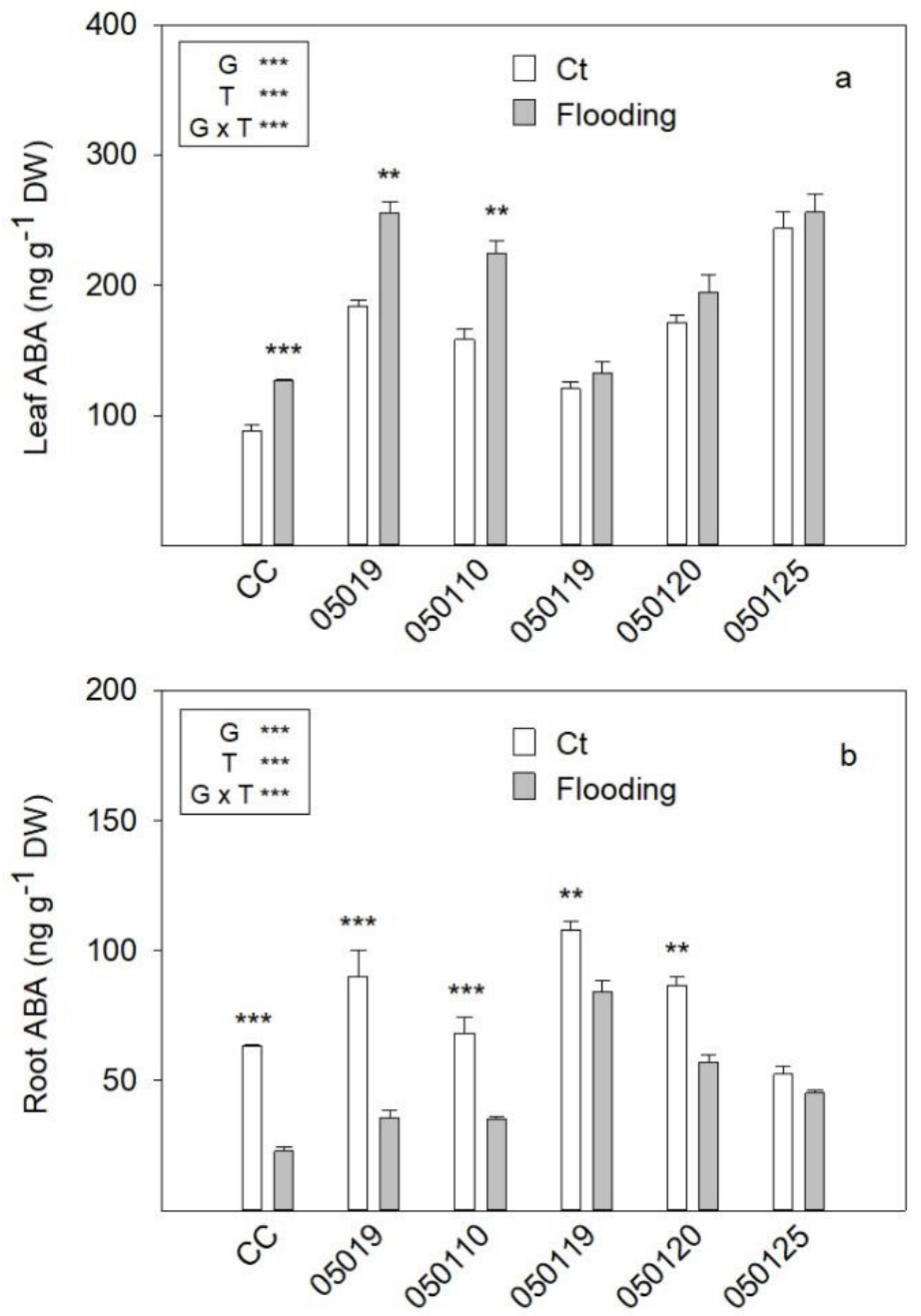

Figure 7. Abscisic acid concentration (ABA) in (a) the leaves and (b) roots of five citrus hybrids grown for 35 days in the non-stressed $(\mathrm{Ct})$ or flooding treatment. Values are the means of six independent seedlings $(n=6)$. In each hybrid, comparisons among treatments were made by Fisher's least significance difference (LSD) test. ${ }^{* *} p<0.01,{ }^{* * *} p<0.001$. CC: Carrizo citrange; G: genotype, T: treatment.

Under the Ct conditions, 050110 and 050125 presented similar ABA concentrations in roots (Figure $7 \mathrm{~b}$ ) as in CC (mean value of $61.2 \pm 8.0$ ), while $050119 \mathrm{Ct}$ obtained the highest value throughout the experiment $\left(107.9 \mathrm{ng} \cdot \mathrm{g}^{-1} \mathrm{DW}\right)$. Flooding stress lowered the ABA concentration in the roots of most hybrids. The greatest reduction was observed in CC and 05019 (around 60\% decrease), while the lowest reduction was seen for $050119(22.1 \%)$. The tendency observed in 050125 was not statistically significant.

\subsection{PIP Gene Expression}

Figure 8 shows the relative expression of the genes coding two aquaporins related to the water relations in cell roots. Under the Ct conditions, all the 0501 hybrids displayed a higher PIP1 expression than the Ct rootstock CC (Figure 8a). Most ranged from 2.7to 3.2-fold, and even 7.8-fold was noted in the 050120 hybrid. Flooding decreased the 
PIP1 gene expression in CC (63.7\% lower) and three hybrids (05019, 050110, and 050119) with decreases between $44.9 \%$ and $7 \%$. PIP1 expression did not reduce in hybrids 050120 and 050125 .
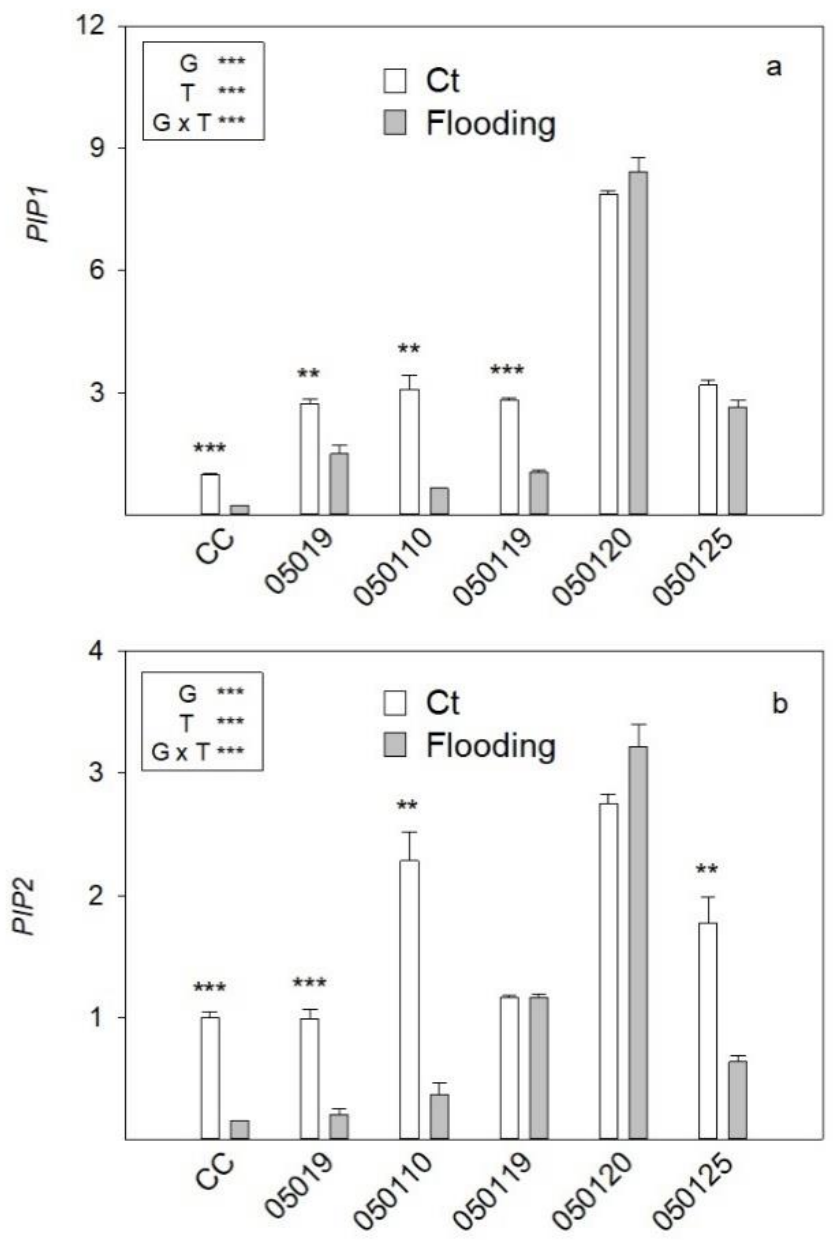

Figure 8. (a) PIP1 and (b) PIP2 relative expression levels in the roots of five citrus hybrids grown for 35 days in the non-stressed $(\mathrm{Ct})$ or flooding treatment. The values are means of six independent seedlings $(n=6)$. In each hybrid, comparisons among treatments were made by Fisher's least significance difference (LSD) test. ${ }^{* *} p<0.01,{ }^{* * *} p<0.001$. CC: Carrizo citrange; G: genotype, T: treatment.

CC, 0509, and 050119 had a similar PIP2 expression (Figure 8b) under the $\mathrm{Ct}$ conditions, which rose by 2.3-, 3.3- and 1.8-fold in 050110, 050120, and 050125, respectively, vs. CC Ct. In this case, flooding decreased the PIP2 expression in CC by $84.0 \%$ and in two hybrids (05019 and 050110 ) by 38.8 and $41.6 \%$, respectively. However, the PIP2 expression in the 050120 roots increased by $10.3 \%$ with flooding stress.

\subsection{Correlation Analysis}

The pairwise coefficients showed a positive correlation and a statistical significance for 43 of the 91 pairs (Table 2). The combinations $g_{s}$ vs. E and An vs. both efficiencies (An/Ci and An/E) revealed the strongest correlations ( $r=0.976$ to 0.938$)$. An, E, and $\mathrm{g}_{\mathrm{s}}$ also correlated with fluorescence $\mathrm{Fv} / \mathrm{Fm}$, chlorophyll concentration, and both leaf potentials, as did $\mathrm{E}$ and $\mathrm{g}_{\mathrm{s}}$ with the expression of both PIPs. Moderate and positive correlations were observed in the pairs' ABA concentration in the root vs. chlorophyll concentration vs. $\mathrm{Fv} / \mathrm{Fm}$ and osmotic potential ( $r=0.672$ to 0.578$)$. 


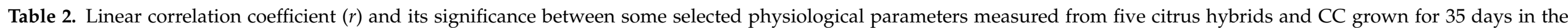

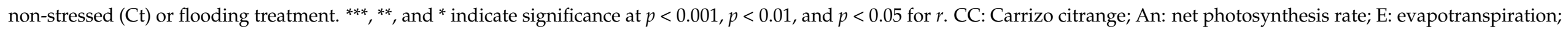

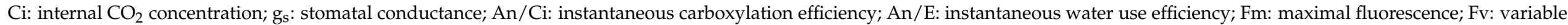
fluorescence; Chl: chlorophyll; ABA: abscisic acid; $\Psi \omega$ : leaf water potential; $\Psi_{\pi}$ : leaf osmotic potential; PIP: aquaporin.

\begin{tabular}{|c|c|c|c|c|c|c|c|c|c|c|c|c|c|}
\hline & $\mathrm{E}$ & $\mathbf{C i}$ & $\mathrm{g}_{\mathrm{s}}$ & $\mathrm{An} / \mathrm{C} \mathbf{i}$ & An/E & Fv/Fm & Chl $a+b$ & $\begin{array}{r}\text { Leaf } \\
\text { ABA }\end{array}$ & $\begin{array}{l}\text { Root } \\
\text { ABA }\end{array}$ & $\Psi \omega$ & $\Psi_{\pi}$ & Pip1 & Pip2 \\
\hline An & $0.868^{* * *}$ & $-0.918^{* * *}$ & $0.848^{* * *}$ & $0.960 * * *$ & $0.938^{* * *}$ & $0.687 *$ & $0.843^{* * *}$ & -0.130 & 0.416 & $0.723^{* *}$ & $0.621 *$ & 0.2296 & 0.455 \\
\hline $\mathrm{E}$ & & -0.728 ** & $0.976^{* * *}$ & $0.743^{* *}$ & 0.789 ** & 0.750 ** & 0.722 ** & -0.154 & 0.505 & $0.798^{* *}$ & $0.729^{* *}$ & 0.5779 * & $0.712^{* *}$ \\
\hline $\mathrm{Ci}$ & & & $-0.6672 *$ & $-0.924^{* * *}$ & $-0.992 * * *$ & -0.640 * & $-0.871^{* * *}$ & 0.293 & -0.567 & $-0.779 * *$ & -0.554 & -0.092 & -0.334 \\
\hline $\mathrm{g}_{\mathrm{s}}$ & & & & $0.726^{* *}$ & $0.719^{* *}$ & $0.737^{* *}$ & 0.699 * & -0.128 & 0.479 & 0.707 * & 0.701 * & $0.577^{*}$ & $0.7251^{* *}$ \\
\hline $\mathrm{An} / \mathrm{Ci}$ & & & & & $0.923^{* * *}$ & 0.578 * & $0.7629^{* *}$ & -0.085 & 0.352 & 0.634 * & 0.574 * & 0.140 & 0.411 \\
\hline $\mathrm{An} / \mathrm{E}$ & & & & & & 0.688 * & $0.877^{* * *}$ & -0.295 & 0.559 & $0.819^{* *}$ & $0.588^{*}$ & 0.154 & 0.384 \\
\hline $\mathrm{Fv} / \mathrm{Fm}$ & & & & & & & $0.818^{* *}$ & -0.393 & 0.594 * & $0.791 * *$ & 0.683 * & 0.333 & 0.428 \\
\hline Chl $a+b$ & & & & & & & & -0.417 & $0.672 *$ & $0.767 * *$ & 0.489 & 0.117 & 0.256 \\
\hline Leaf ABA & & & & & & & & & -0.442 & -0.362 & 0.042 & 0.143 & -0.078 \\
\hline Root ABA & & & & & & & & & & 0.569 & 0.524 & 0.327 & 0.415 \\
\hline$\Psi \omega$ & & & & & & & & & & & $0.656^{*}$ & 0.296 & 0.381 \\
\hline$\Psi_{\pi}$ & & & & & & & & & & & & 0.469 & 0.578 * \\
\hline Pip1 & & & & & & & & & & & & & $0.890^{* * *}$ \\
\hline
\end{tabular}


Negative correlations were observed in eight of 91 pairs and were all related to the internal $\mathrm{CO}_{2}$ concentration. $\mathrm{Ci}$ negatively correlated with all the gas exchange parameters (An, $\mathrm{g}_{\mathrm{s}}, \mathrm{E}$ ) and their efficiencies (ranging from $r=-0.67$ to $r=-0.99$ ). A strong correlation was recorded in $\mathrm{Ci}$ vs. fluorescence parameter $\mathrm{Fv} / \mathrm{Fm}$, vs. chlorophyll concentration, and vs. the water potential in leaves $(r=-0.64,-0.87$, and -0.78 , respectively).

\section{Discussion}

Seedlings presented visible treatment symptoms 35 days after exposure to flooding stress. Symptoms were mainly reduced plant biomass and chlorotic leaf yellowing, as well as a depressive effect on some physiological parameters such as leaf $\mathrm{Chl}$ and photosynthesis, together with alteration of other traits associated with water relations in plants.

Regarding biomass, flooding stress dramatically decreased total plant growth compared to the $\mathrm{Ct}$ seedlings. Our findings are consistent with previous studies conducted in citrus. Wu et al. [45] reported a significant reduction in plant height, stem diameter, and shoot and root FW in flooded plants under a prolonged 37 day waterlogging condition. Partiya et al. [11] also documented significant plant growth inhibition under flooding conditions when analyzed in several rootstocks often used in citrus orchards (C. aurantium L. 'sour orange', C. jambhiri Lush. 'rough lemon', Poncirus trifoliata Raf. 'Trifoliate orange', and C. sinensis (L.) Osb. $\times$ P. trifoliata (L.) Raft. 'Troyer citrange'). Differences appeared between our hybrids. While the biomass of the $\mathrm{Ct}$ rootstock $\mathrm{CC}$ was markedly reduced in all the plant fractions, the root system of hybrid 050119 was apparently less sensitive to flooding than the other hybrids; it displayed significant leaf DW reduction and, consequently, a higher root-shoot ratio than the Ct seedlings. This result suggests the formation of adventitious roots, which has been described as an adaptive response to waterlogging in many plants such as tomato [46], Rumex [47], sunflower, sugarcane [48], and Mentha [49]. These new roots functionally replace basal ones, which typically decay in waterlogging procedures and are, therefore, incapable of supplying the water and minerals that plants require [50]. However, the biomass of hybrid 050110 did not decrease in the aerial part under the flooding conditions. Altogether, these data suggest the dependence of the genotype on the final response to stress, which agrees with not only previous studies conducted on citrus in flooding treatments, but also other abiotic stresses $[7,8,10,11]$.

Similarly, the leaf $\mathrm{Chl}$ of the flooding-stressed leaves was also reduced in all the genotypes, which is compatible with chlorotic yellowing in leaves. Visible leaf damage in flooded citrus plants (from the initial midrib yellowing, subsequent leaf yellow spots, and finally wilting) was well characterized by Hossain et al. (2009) during a time-course of flooding stress. Our results are consistent with previous studies also carried out in citrus under waterlogging conditions $[10,11]$, as well as with those that also compared different rootstocks [23]. In contrast, [11] observed a rootstock influence on Chl content in waterlogged seedlings, where the total Chl content lowered in most of the studied genotypes, but not in Rough lemon and the Iranian local variety CRC2. The authors of [51] also reported substantial leaf damage and reduced chlorophyll content in Citrumelo and Cleopatra mandarin after long-term flooding stress (20 days), while no reduction in Chl and less leaf damage were observed in CC. Moreover, from the correlation analysis, we found that the seedlings with a marked drop in $\mathrm{Chl}$ (reduction in the light-harvesting pigments content) also correlated with a drastic drop in the An rate and fluorescence parameter Fv /Fm (Figure 5). Strong correlations between An and Fv/Fm, as well as intercellularly to the ambient $\mathrm{CO}_{2}$ ratio $(\mathrm{Ci} / \mathrm{Ca})$ and FPSII, have also been observed in citrus [51].This outlook has been related to the reduction/impairment in the activity of stroma enzymes and the photosynthetic electron transport rate [52], as well as to low radicular permeability to water diffusion [27].

Waterlogging also brought about a drastic drop in $\mathrm{E}$ and $\mathrm{g}_{\mathrm{s}}$ in most hybrids, which correlated with a marked reduction in An. Under these stomatal closure conditions, increased resistance to the $\mathrm{CO}_{2}$ entering leaves would be expected and, consequently, low Ci levels, as previously reported in other flooding studies (Farquhar and Sharkey, 
1982). Thus, An reduction would mainly derive from the mechanical impairment of $\mathrm{CO}_{2}$ entering leaves and, consequently, low $\mathrm{Ci}$ available for photosynthesis reactions. Accordingly, $[31,53]$ reported reductions in $\mathrm{A}$ and $\mathrm{g}_{\mathrm{s}}$, as well as in $\mathrm{Ci}$, within $24 \mathrm{~h}$ of flooding blueberry plants, which supports their hypothesis that $\mathrm{g}_{\mathrm{s}}$ limits $\mathrm{An}$ in blueberries under these conditions. However, the $\mathrm{Ci}$ in our study was notably high, very close to the reference value in many cases, and negatively correlated with An, which all suggest that another kind of regulation was involved. This conclusion was also reached by [4,54] in kiwifruit, who related stomatal regulation under flooding stress to other processes, such as a low soil oxygen concentration, increased leaf ABA levels, and a higher $\mathrm{CO}_{2}$ concentration caused by importing gas from soil or by photosynthetic apparatus injury. In the same line, [31,53] observed a subsequent decrease in residual conductance when waterlogging lasted for longer periods and $\mathrm{Ci}$ increased a few days after flooding. In our study, gas exchange was not determined during a time-course experiment after flooding was imposed, and residual conductance was not determined. Therefore, sequential observations of flooded plants may detect an initial decrease, followed by an increase in Ci due to long-term exposure. Moreover, the low efficiency of carboxylation reactions in waterlogged seedlings (An/Ci) indicated that flooding stress affected photosynthesis in two ways: (1) stomatal closure; (2) metabolic limitations, likely the inhibition of mesophyll conductance and/or photochemical efficiency [55-57]. A similar conclusion was reached in citrus grown under drought stress, where a reduction in the ability to fix $\mathrm{CO}_{2}$ was not only associated with stomatal factors, but also with a drop in photosynthetic electron flow [58]. Water use efficiency (An/E) remained unaltered in four genotypes, caused by considerable stomata closure associated with a drop in the transpiration rate [51], as also reported for water or salt stresses [8]. On the whole, the considerable reduction in the carbon assimilation rate brought about reduced vegetative growth in all the tested genotypes (Figure 1).

From the correlation analysis, stomatal conductance correlated positively with the water potentials in seedlings. The waterlogged plant response to stress by stomata closure also maintained a balanced water status in the leaf mesophyll. Similar results have been reported in other studies [10,11], even under different stresses such as Fe deficiency and the presence of salt or bicarbonate $[7,8,52]$. On the contrary, no reduction as seen in hybrid 050120, and even a higher $\mathrm{g}_{\mathrm{s}}$ value have been suggested for stomatal control mechanism loss [53]. It is well known that stresses, particularly those related to plant hydric relations, such as salinity, flooding, or drought, lower $\Psi \omega$, which is compensated for by a drop in leaf $\Psi \pi$ to maintain leaf turgor with values close to those of the Ct plants $[59,60]$. Although the $\Psi \omega$ of all the 0501 seedlings decreased with flooding, some displayed a less marked reduction in $\Psi \pi$ than others, such as 050120 , or no effect, such as 05019,050119 and 050120 (Figure 6). This behavior suggests that these genotypes have a better osmotic adjustment mechanism and apparently better tolerance response. In line with this result, Syvertsen and Garcia-Sanchez [59] reported the relationship between stomata closure and low leaf transpiration, which limits the translocation of ions [61,62].

All the 0501 hybrids in this study had higher ABA concentrations in leaves than $\mathrm{CC}$, and levels remained under the flooding conditions or even significantly increased. In this situation, stomatal closure is mainly regulated by increased leaf $A B A$ to prevent dehydration. However, in our experiments, the ABA concentration in roots was lowered. A similar pattern was observed in the CC plants submitted to waterlogging, where leaf ABA progressively increased over time to become statistically significant 21 days after soil inundation, and it was up to 2.7-fold higher in mature leaves at 35 days [20]. In contrast, the ABA in roots and xylem decreased more than $90 \%$ after 15 days of flooding, and it was almost undetectable after 35 days (Rodriguez-Gamir et al. (2011). The endogenous levels of some plant hormones, including $\mathrm{ABA}$ and jasmonic acid, were notably lowered in the roots of the Citrumelo, CC, and Cleopatra mandarin genotypes at an early stage (5 days) in a long-term flooding experiment ( 35 days), while the leaf ABA concentration depended more on the rootstock [21], where significantly statistical ABA accumulation occurred 6 days after flooding for sensitive rootstock CM, but was delayed to 20 days 
and 14 days in Citrumelo and CC, respectively. This also happened in other experiments performed in citrus rootstocks with flooding stress, but without any other stress types like drought [58]. It is known that flooding reduces both water uptake and root hydraulic conductance [20,63], as shown by the lowered gene expression of PIP aquaporins herein. This fact implies a link between root and leaf sensing that signals changes in the root water and oxygen balance $[64,65]$. The HCR1 gene (HYDRAULIC CONDUCTIVITY OF ROOT 1) is known to explain the root hydraulic drop by $\mathrm{K}^{+}$availability and $\mathrm{O}_{2}$ status [66], which can be explained by increased leaf ABA and diminished root ABA (Figure 7). Hence, a high basal transpiration rate like that in 050125 could be an important factor for defining soil flooding tolerance and subsequent recovery [51,67].

Otherwise, the reduction in the expression of the PIP1 and PIP2 aquaporin genes in all the studied hybrids (Figure 8), which also positively correlated with parameters $\mathrm{E}$ and $\mathrm{g}_{\mathrm{s}}$, suggests the impairment of the functional water channels at the plasma membrane during prolonged waterlogging. The plasma membrane's intrinsic proteins were downregulated with a low $\mathrm{pH}$, which derived from the oxygen deprivation conditions, in turn hampering the water influx in the cell [37]. This finding agrees with the reduced plant DW in the waterlogged seedlings, which has been related to a lower water content because of less root hydraulic conductance [68]. Lack of water entering would involve an osmotic adjustment inside the cell, as reflected in the correlation analysis. Along the same lines, a drastic reduction in PIP expression in CC was also related to the acidosis induced by anoxic stress, as the $\mathrm{pH}$ in solution notably dropped from the beginning of the assay [20].

\section{Conclusions}

From this study, we conclude that 0501 genotypes develop some adaptive responses in plants against flooding stress, such as (1) stomata closure in leaves to prevent water loss, likely mediated by the high ABA levels found in these organs, and (2) enhanced water and osmotic potentials, as well as the downregulation of the genes regulating aquaporin channels to maintain water relations in plants. These traits seemed particularly relevant in hybrids 050110 and 050125 . Although this work performed exhaustive initial screening to find new tolerant genotypes to waterlogging, further experiments must be done to determine their behavior under field conditions, especially to determine their influence on commercial varieties when grafted.

Author Contributions: Conceptualization, M.-R.M.-C. and M.Á.F.-G.; data curation, M.Á.F.-G.; formal analysis, M.-R.M.-C.; funding acquisition, M.Á.F.-G.; investigation, M.-R.M.-C. and A.P.-C.; methodology, M.-R.M.-C. and A.P.-C.; supervision, M.-R.M.-C. and M.Á.F.-G.; validation, M.-R.M.-C. and A.P.-C; writing-original draft, M.-R.M.-C.; writing—review and editing, A.P.-C. and M.Á.F.-G. All authors were informed about each step of manuscript processing including submission and revision via emails from our system or the assigned Assistant Editor. All authors read and agreed to the published version of the manuscript.

Funding: This study was cofunded by the Ministerio de Ciencia e Innovación (RTI2018-098379-R-I00) and by the European Union through the European Regional Development Fund (ERDF) of the Generalitat Valenciana 2014-2020 (IVIA-51913).

Institutional Review Board Statement: Not applicable.

Informed Consent Statement: Not applicable.

Data Availability Statement: Not applicable.

Acknowledgments: This work was funded by the Instituto Nacional de Investigación y Tecnología Agraria y Alimentaria (RTA2011-00127), the Generalitat Valenciana, and FEDER funds. We thank Carmen Casamayor, Almudena Bermejo, and Jesús Asensi for their laboratory and technical support.

Conflicts of Interest: The authors declare no conflict of interest. 


\begin{abstract}
Abbreviations
ABA: abscisic acid; CC: Carrizo citrange; Chl: chlorophyll concentration; An: net photosynthesis rate; gs: stomatal conductance; $\mathrm{Ci}$ : internal $\mathrm{CO}_{2}$ concentration; $\mathrm{E}$ : evapotranspiration; Fo: minimal fluorescence; Fm: maximal fluorescence; Fv: variable fluorescence; $\Psi_{\mathrm{s}}$ : leaf water potential; $\Psi_{\pi}$ : leaf osmotic potential DW: dry weight; FW: fresh weight; TW: turgid weigh; RWC: relative water content.
\end{abstract}

\title{
References
}

1. Sullivan, M.; Vantoai, T.; Fausey, N.R.; Beuerlein, J.; Parkinson, R.; Soboyejo, A. Evaluating On-Farm Flooding Impacts on Soybean. Crop Sci. 2001, 41, 93-100. [CrossRef]

2. Schaffer, B.; Davies, F.S.; Crane, J.H. Responses of Subtropical and Tropical Fruit Trees to Flooding in Calcareous Soil. HortScience 2006, 41, 549-555. [CrossRef]

3. Colmer, T.D.; Voesenek, L.A.C.J. Flooding tolerance: Suites of plant traits in variable environments. Funct. Plant Biol. 2009, 36, 665-681. [CrossRef] [PubMed]

4. Bhusal, R.; Mizutani, F.; Rutto, K. Selection of Rootstocks for Flooding and Drought Tolerance in Citrus Species. Pak. J. Biol. Sci. 2002, 5, 509-512. [CrossRef]

5. Forner-Giner, M.A.; Llosá, M.J.; Carrasco, J.L.; Perez-Amador, M.A.; Navarro, L.; Ancillo, G. Differential gene expression analysis provides new insights into the molecular basis of iron deficiency stress response in the citrus rootstock Poncirus trifoliata (L.) Raf. J. Exp. Bot. 2009, 61, 483-490. [CrossRef]

6. Martínez-Cuenca, M.-R.; Forner-Giner, M.Á.; Iglesias, D.J.; Primo-Millo, E.; Legaz, F. Strategy I responses to Fe-deficiency of two Citrus rootstocks differing in their tolerance to iron chlorosis. Sci. Hortic. 2013, 153, 56-63. [CrossRef]

7. Martínez-Cuenca, M.-R.; Quiñones, A.; Forner-Giner, M.Á. Screening of 'King' mandarin (Citrus nobilis Lour) $\times$ Poncirus trifoliata ((L.) Raf.) hybrids as citrus rootstocks tolerants to iron chlorosis. Sci. Hortic. 2016, 198, 61-69. [CrossRef]

8. Martínez-Cuenca, M.-R.; Primo-Capella, A.; Forner-Giner, M.Á. Screening of 'King' mandarin (Citrus nobilis Lour) $\times$ Poncirus trifoliata ((L.) Raf.) hybrids as salt stress-tolerant citrus rootstocks. Hortic. Environ. Biotechnol. 2021, 62, 337-351. [CrossRef]

9. García-Sánchez, F.; Syvertsen, J.P.; Gimeno, V.; Botía, P.; Perez-Perez, J.G. Responses to flooding and drought stress by two citrus rootstock seedlings with different water-use efficiency. Physiol. Plant. 2007, 130, 532-542. [CrossRef]

10. Martínez-Cuenca, M.-R.; Quiñones, A.; Primo-Millo, E.; Forner-Giner, M.Á. Flooding Impairs Fe Uptake and Distribution in Citrus Due to the Strong Down-Regulation of Genes Involved in Strategy I Responses to Fe Deficiency in Roots. PLoS ONE 2015, 10, e0123644. [CrossRef]

11. Partiya, R.; Fotouhi Ghazvini, R.; Fifaei, R.; Ghasemnezhad, M. Response of Different Citrus Genotypes to Continuous Flooding Conditions. Int. J. Hortic. Sci. Technol. 2018, 5, 253-263. [CrossRef]

12. Syvertsen, J.P.; Zablotowicz, R.M.; Smith, M.L. Soil temperature and flooding effects on two species of citrus. Plant Soil 1983, 72, 3-12. [CrossRef]

13. Forner, J.B.; Forner-Giner, M.A.; Alcaide, A. Forner-Alcaide 5 and Forner-Alcaide 13: Two New Citrus Rootstocks Released in Spain. HortScience 2003, 38, 629-630. [CrossRef]

14. Forner-Giner, M.A.-M. Performance of Forner-Alcaide 5 and Forner-Alcaide 13, hybrids of Cleopatra mandarin $\times$ Poncirus trifoliate, as Salinity-Tolerant Citrus Rootstocks. J. Am. Pomol. Soc. 2009, 63, 72.

15. González-Mas, M.C.; Llosa, M.J.; Quijano, A.; Forner-Giner, M.A. Rootstock Effects on Leaf Photosynthesis in 'Navelina' Trees Grown in Calcareous Soil. HortScience 2009, 44, 280-283. [CrossRef]

16. Yang, Z.-N.; Ye, X.-R.; Molina, J.; Roose, M.L.; Mirkov, T.E. Sequence analysis of a 282-kilobase region surrounding the citrus Tristeza virus resistance gene (Ctv) locus in Poncirus trifoliata L. Raf. Plant Physiol. 2003, 131, 482-492. [CrossRef]

17. Martínez-Cuenca, M.-R.; Iglesias, D.J.; Forner-Giner, M.A.; Primo-Millo, E.; Legaz, F. The effect of sodium bicarbonate on plant performance and iron acquisition system of FA-5 (Forner-Alcaide 5) citrus seedlings. Acta Physiol. Plant. 2013, 35, $2833-2845$. [CrossRef]

18. Syvertsen, J.P.; Lloyd, J.; Kriedemann, P.E. Salinity and drought stress effects on foliar ion concentration, water relations, and photosynthetic characteristics of orchard citrus. Aust. J. Agric. Res. 1988, 39, 619-627. [CrossRef]

19. Bailey-Serres, J.; Voesenek, L.A.C.J. Flooding Stress: Acclimations and Genetic Diversity. Annu. Rev. Plant Biol. 2008, 59, 313-339. [CrossRef]

20. Rodríguez-Gamir, J.; Ancillo, G.; González-Mas, M.C.; Primo-Millo, E.; Iglesias, D.J.; Forner-Giner, M.A. Root signalling and modulation of stomatal closure in flooded citrus seedlings. Plant Physiol. Biochem. 2011, 49, 636-645. [CrossRef]

21. Arbona, V.; Gómez-Cadenas, A. Hormonal Modulation of Citrus Responses to Flooding. J. Plant Growth Regul. 2008, $27,241$. [CrossRef]

22. Pezeshki, S.R. Wetland plant responses to soil flooding. Environ. Exp. Bot. 2001, 46, 299-312. [CrossRef]

23. Vu, J.C.V.; Yelenosky, G. Photosynthetic responses of citrus trees to soil flooding. Physiol. Plant. 1991, 81, 7-14. [CrossRef]

24. Martínez-Alcántara, B.; Jover, S.; Quiñones, A.; Forner-Giner, M.Á.; Rodríguez-Gamir, J.; Legaz, F.; Primo-Millo, E.; Iglesias, D.J. Flooding affects uptake and distribution of carbon and nitrogen in citrus seedlings. J. Plant Physiol. 2012, 169, 1150-1157. [CrossRef] 
25. Arbona, V.; Hossain, Z.; López-Climent, M.F.; Pérez-Clemente, R.M.; Gómez-Cadenas, A. Antioxidant enzymatic activity is linked to waterlogging stress tolerance in citrus. Physiol. Plant. 2008, 132, 452-466. [CrossRef]

26. Argamasilla, R.; Gómez-Cadenas, A.; Arbona, V. Metabolic and Regulatory Responses in Citrus Rootstocks in Response to Adverse Environmental Conditions. J. Plant Growth Regul. 2014, 33, 169-180. [CrossRef]

27. Ruiz-Sánchez, M.C.; Domingo, R.; Morales, D.; Torrecillas, A. Water relations of Fino lemon plants on two rootstocks under flooded conditions. Plant Sci. 1996, 120, 119-125. [CrossRef]

28. Birner, T.P.; Steudle, E. Effects of anaerobic conditions on water and solute relations, and on active transport in roots of maize (Zea mays L.). Planta 1993, 190, 474-483. [CrossRef]

29. Ehlert, C.; Maurel, C.; Tardieu, F.; Simonneau, T. Aquaporin-Mediated Reduction in Maize Root Hydraulic Conductivity Impacts Cell Turgor and Leaf Elongation Even without Changing Transpiration. Plant Physiol. 2009, 150, 1093-1104. [CrossRef]

30. Andersen, P.C.; Lombard, P.B.; Westwood, M.N. Effect of root anaerobiosis on the water relations of several Pyrus species. Physiol. Plant. 1984, 62, 245-252. [CrossRef]

31. Davies, F.S.; Flore, J.A. Flooding, gas exchange and hydraulic root conductivity of highbush blueberry. Physiol. Plant. 1986, 67, 545-551. [CrossRef]

32. Else, M.A.; Davies, W.J.; Malone, M.; Jackson, M.B. A Negative Hydraulic Message from Oxygen-Deficient Roots of Tomato Plants? (Influence of Soil Flooding on Leaf Water Potential, Leaf Expansion, and Synchrony between Stomatal Conductance and Root Hydraulic Conductivity). Plant Physiol. 1995, 109, 1017-1024. [CrossRef] [PubMed]

33. Else, M.A.; Coupland, D.; Dutton, L.; Jackson, M.B. Decreased root hydraulic conductivity reduces leaf water potential, initiates stomatal closure and slows leaf expansion in flooded plants of castor oil (Ricinus communis) despite diminished delivery of ABA from the roots to shoots in xylem sap. Physiol. Plant. 2001, 111, 46-54. [CrossRef]

34. Forrest, K.L.; Bhave, M. Major intrinsic proteins (MIPs) in plants: A complex gene family with major impacts on plant phenotype. Funct. Integr. Genom. 2007, 7, 263. [CrossRef] [PubMed]

35. Maurel, C.; Verdoucq, L.; Luu, D.-T.; Santoni, V. Plant Aquaporins: Membrane Channels with Multiple Integrated Functions. Annu. Rev. Plant Biol. 2008, 59, 595-624. [CrossRef]

36. Javot, H.; Maurel, C. The Role of Aquaporins in Root Water Uptake. Ann. Bot. 2002, 90, 301-313. [CrossRef]

37. Tournaire-Roux, C.; Sutka, M.; Javot, H.; Gout, E.; Gerbeau, P.; Luu, D.-T.; Bligny, R.; Maurel, C. Cytosolic pH regulates root water transport during anoxic stress through gating of aquaporins. Nature 2003, 425, 393-397. [CrossRef]

38. Moran, R.; Porath, D. Chlorophyll Determination in Intact Tissues Using N,N-Dimethylformamide. Plant Physiol. 1980, 65, 478-479. [CrossRef]

39. Gaskin, P.; MacMillan, J. Discussion of spectra of TMSI ester TMSI ethers. In GCeMS of the Gibberellins and Related Compounds: Methodology and a Library of Spectra; University of Bristol: Bristol, UK, 1991.

40. Bustin, S.A. Quantification of mRNA using real-time reverse transcription PCR (RT-PCR): Trends and problems. J. Mol. Endocrinol. 2002, 29, 23-39. [CrossRef]

41. Pfaffl, M.W. A new mathematical model for relative quantification in real-time RT-PCR. Nucleic Acids Res. 2001, 29, e45. [CrossRef]

42. Agüero, J.; del Carmen Vives, M.; Velázquez, K.; Pina, J.A.; Navarro, L.; Moreno, P.; Guerri, J. Effectiveness of gene silencing induced by viral vectors based on Citrus leaf blotch virus is different in Nicotiana benthamiana and citrus plants. Virology 2014, 460-461, 154-164. [CrossRef]

43. Estornell, L.H.; Gómez, M.D.; Pérez-Amador, M.A.; Talón, M.; Tadeo, F.R. Secondary abscission zones: Understanding the molecular mechanisms triggering stylar abscission in citrus. Acta Hortic. 2016, 1119, 65-72. [CrossRef]

44. Brunner, A.M.; Yakovlev, I.A.; Strauss, S.H. Validating internal controls for quantitative plant gene expression studies. BMC Plant Biol. 2004, 4, 14. [CrossRef]

45. Wu, Q.-S.; Zou, Y.-N.; Huang, Y.-M. The arbuscular mycorrhizal fungus Diversispora spurca ameliorates effects of waterlogging on growth, root system architecture and antioxidant enzyme activities of citrus seedlings. Fungal Ecol. 2013, 6, 37-43. [CrossRef]

46. Vidoz, M.L.; Loreti, E.; Mensuali, A.; Alpi, A.; Perata, P. Hormonal interplay during adventitious root formation in flooded tomato plants. Plant J. 2010, 63, 551-562. [CrossRef]

47. Liu, Y.; Tikunov, Y.; Schouten, R.E.; Marcelis, L.F.M.; Visser, R.G.F.; Bovy, A. Anthocyanin Biosynthesis and Degradation Mechanisms in Solanaceous Vegetables: A Review. Front. Chem. 2018, 6, 52. [CrossRef]

48. Jackson, W.T. The Role of Adventitious Roots in Recovery of Shoots Following Flooding of the Original Root Systems. Am. J. Bot. 1955, 42, 816-819. [CrossRef]

49. Phukan, U.J.; Mishra, S.; Timbre, K.; Luqman, S.; Shukla, R.K. Mentha arvensis exhibit better adaptive characters in contrast to Mentha piperita when subjugated to sustained waterlogging stress. Protoplasma 2014, 251, 603-614. [CrossRef]

50. Gibberd, M.R.; Gray, J.D.; Cocks, P.S.; Colmer, T.D. Waterlogging Tolerance Among a Diverse Range of Trifolium Accessions is Related to Root Porosity, Lateral Root Formation and 'Aerotropic Rooting'. Ann. Bot. 2001, 88, 579-589. [CrossRef]

51. Arbona, V.; López-Climent, M.F.; Pérez-Clemente, R.M.; Gómez-Cadenas, A. Maintenance of a high photosynthetic performance is linked to flooding tolerance in citrus. Environ. Exp. Bot. 2009, 66, 135-142. [CrossRef]

52. Chouliaras, V.; Therios, I.; Molassiotis, A.; Patakas, A.; Diamantidis, G. Effect of Iron Deficiency on Gas Exchange and Catalase and Peroxidase Activity in Citrus. J. Plant Nutr. 2005, 27, 2085-2099. [CrossRef]

53. Davis, T.D.; Jolley, V.D.; Valser, R.H.; Brown, J.C.; Blaylock, A.D. Net photosynthesis of Fe-efficient and Fe-inefficient soybean cultivars grown under varying iron levels. J. Plant Nutr. 1986, 9, 671-681. [CrossRef] 
54. Savé, R.; Serrano, L. Some physiological and growth responses of kiwi fruit (Actinidia chinensis) to flooding. Physiol. Plant. 1986, 66, 75-78. [CrossRef]

55. Paul, M.J.; Driscoll, S.P.; Lawlor, D.W. Sink-Regulation of Photosynthesis in Relation to Temperature in Sunflower and Rape. J. Exp. Bot. 1992, 43, 147-153. [CrossRef]

56. Flexas, J.; Bota, J.; Escalona, J.M.; Sampol, B.; Medrano, H. Effects of drought on photosynthesis in grapevines under field conditions: An evaluation of stomatal and mesophyll limitations. Funct. Plant Biol. 2002, 29, 461-471. [CrossRef]

57. López-Serrano, L.; Penella, C.; San-Bautista, A.; López-Galarza, S.; Calatayud, A. Physiological changes of pepper accessions in response to salinity and water stress. Span. J. Agric. Res. 2017, 15. [CrossRef]

58. Arbona, V.; Zandalinas, S.I.; Manzi, M.; González-Guzmán, M.; Rodriguez, P.L.; Gómez-Cadenas, A. Depletion of abscisic acid levels in roots of flooded Carrizo citrange (Poncirus trifoliata L. Raf. $\times$ Citrus sinensis L. Osb.) plants is a stress-specific response associated to the differential expression of PYR/PYL/RCAR receptors. Plant Mol. Biol. 2017, 93, 623-640. [CrossRef]

59. García-Sánchez, F.; Syvertsen, J.P. Salinity Tolerance of Cleopatra Mandarin and Carrizo Citrange Citrus Rootstock Seedlings Is Affected by $\mathrm{CO}_{2}$ Enrichment during Growth. J. Am. Soc. Hortic. Sci. Jashs 2006, 131, 24-31. [CrossRef]

60. Pérez-Pérez, J.G.; Syvertsen, J.P.; Botía, P.; García-Sánchez, F. Leaf Water Relations and Net Gas Exchange Responses of Salinized Carrizo Citrange Seedlings during Drought Stress and Recovery. Ann. Bot. 2007, 100, 335-345. [CrossRef]

61. Gómez-Cadenas, A.; Iglesias, D.J.; Arbona, V.; Colmenero-Flores, J.M.; Primo-Millo, E.; Talón, M. Physiological and molecular responses of citrus to salinity. In Recent Research Developments in Plant Molecular Biology. Vol. 1, Part II; Research Signpost: Trivandrum, India, 2003; pp. 281-298. ISBN 8127100099.

62. Syvertsen, J.P.; Garcia-Sanchez, F. Multiple abiotic stresses occurring with salinity stress in citrus. Environ. Exp. Bot. 2014, 103, 128-137. [CrossRef]

63. Else, M.A.; Janowiak, F.; Atkinson, C.J.; Jackson, M.B. Root signals and stomatal closure in relation to photosynthesis, chlorophyll a fluorescence and adventitious rooting of flooded tomato plants. Ann. Bot. 2009, 103, 313-323. [CrossRef] [PubMed]

64. Soma, F.; Takahashi, F.; Suzuki, T.; Shinozaki, K.; Yamaguchi-Shinozaki, K. Plant Raf-like kinases regulate the mRNA population upstream of ABA-unresponsive $\mathrm{SnRK}_{2}$ kinases under drought stress. Nat. Commun. 2020, 11, 1373. [CrossRef] [PubMed]

65. Takahashi, Y.; Zhang, J.; Hsu, P.-K.; Ceciliato, P.H.O.; Zhang, L.; Dubeaux, G.; Munemasa, S.; Ge, C.; Zhao, Y.; Hauser, F.; et al. MAP3Kinase-dependent SnRK2-kinase activation is required for abscisic acid signal transduction and rapid osmotic stress response. Nat. Commun. 2020, 11, 12. [CrossRef] [PubMed]

66. González-Guzmán, M.; Gómez-Cadenas, A.; Arbona, V. Abscisic Acid as an Emerging Modulator of the Responses of Plants to Low Oxygen Conditions. Front. Plant Sci. 2021, 12, 755. [CrossRef]

67. Yeung, E.; Bailey-Serres, J.; Sasidharan, R. After The Deluge: Plant Revival Post-Flooding. Trends Plant Sci. 2019, $24,443-454$. [CrossRef]

68. Vandeleur, R.; Niemietz, C.; Tilbrook, J.; Tyerman, S.D. Roles of Aquaporins in Root Responses to Irrigation. Plant Soil 2005, 274, 141. [CrossRef] 